Dementia

and Geriatric

Cognitive Disorders
Dement Geriatr Cogn Disord 2019;47:149-156

This article is licensed under the Creative Commons Attribution-NonCommercial-NoDerivatives 4.0 International License (CC BY-NC-ND) (http://www.karger.com/Services/OpenAccessLicense). Usage and distribu-

tion for commercial purposes as well as any distribution of modified material requires written permission.

\title{
Methods for Involving People Living with Dementia and Their Informal Carers as Co-Developers of Technological Solutions
}

\author{
Helianthe S.M. Kort ${ }^{a, b}$ Bas Steunenberg ${ }^{c}$ Joost van Hoof ${ }^{d, e}$ \\ aResearch group Technologies for Healthcare Innovations, Research Centre Sustainable and \\ Healthy Living, Utrecht University of Applied Sciences, Utrecht, The Netherlands; ${ }^{\text {b Research }}$ \\ group Building Healthy Environments for Future Users, Unit Building Performance and \\ Services, Department of the Built Environment, Eindhoven University of Technology, \\ Eindhoven, The Netherlands; ${ }^{C}$ Research group Dissemination of Pharmaceutical Innovations, \\ Research Centre Sustainable and Healthy Living Utrecht University of Applied Sciences, \\ Utrecht, The Netherlands; ${ }^{\text {}}$ Faculty of Social Work and Education, The Hague University of \\ Applied Sciences, Den Haag, The Netherlands; ${ }^{e}$ Department of Spatial Economy, Faculty \\ of Environmental Engineering and Geodesy, Wrocław University of Environmental and Life \\ Sciences, Wrocław, Poland
}

\section{Keywords}

Participatory design · Autonomy · Ageing-in-place $\cdot$ Inclusion $\cdot$ Methodology $\cdot$ Participant

\begin{abstract}
This paper reports on the research methods used in five different projects aimed at supporting people living with dementia in their everyday lives and activities of daily living. In all five projects, people living with dementia and their informal carers were involved. Applied methods ranged from passive involvement in the form of observations to very active involvement consisting of consultation rounds and think-aloud sessions. The projects highlighted that people living with dementia can still contribute to the development of solutions that support them in the self-management of their symptoms and challenges, as well as technological solutions that support them in daily living.

(C) 2019 The Author(s)

Published by S. Karger AG, Basel
\end{abstract}

\section{Introduction}

Caring for older people has been an essential part of societies all over the world, yet the perspective of caring has shifted. There have been political and societal transitions and technological innovations. In addition, organizational perspectives on caring have changed as the 
focus has expanded from medical cure to holistic care. Furthermore, care has transitioned from passive reception to individual self-management. This shift is also evident in dementia care.

Globally, 50 million individuals were living with dementia in 2017 [1]. Caring for people living with dementia (PwD) begins at home, which is considered to be the safe haven for ageing-in-place. PwD behavioral and psychological symptoms of dementia are associated with an increased risk of nursing home admission [2].

In general, older people will age at home. Ageing comprises certain changes in life; on one hand there is an increasing level of experience, on the other a decrease in physical performance and consequently a gradual decline in physical independence. Older people accommodate to this in ways that are aligned with their lifestyle, through psychological attributes and coping (intraindividual factors) or through use of medication, support from professional care and informal care, or by environmental modifications and use of assistive technologies (extraindividual factors) [3]. All these strategies are used in order to stay independent for as long as possible. This also applies to PwD, who not only have to deal with functional decline but also with cognitive decline. The latter poses additional barriers to accommodate to the changes in life when compared to other older people.

In this paper we focus on how PwD can be involved in the development of environmental modifications, the design of technology, and medication adherence strategies so that they can positively accommodate to the changes in their lives. The goal is to describe methodologies used in these studies, which involve PwD in the development of these extraindividual factors for physical independence.

\section{Materials and Methods}

The methods used for the involvement of PwD are taken from the methodology sections as used in five different projects. The projects considered were: design of a website to provide PwD with information to age-in-place (DAD project); creating an enriched environment for older adults (BEZO project); supporting PwD in their medication adherence (MedGUIDE project); creation of a sense of home in nursing home environments (VETO project), and design of an Automated Asset Management in Nursing Homes (SCHAT project).

\section{Description of the Projects and Participants}

The DAD project took place in 2010 and was initiated on request of the Dutch Alzheimer's Society (DAS). The knowledge and experience related to ageing-in-place for PwD needed to be extended outside the academic world to PwD, informal carers and practitioners. For this project, the DAS recruited volunteers of the society, who were active in several of the DAS working groups. The recruitment of participants was performed digitally. Three couples, in which the husband had early dementia, were willing to participate. All participants had digital skills, although the wives had become the primary operators of the personal computer. The goal was for PwD and family carers to gather and systematically order all information available at that time in a comprehensive manner for other PwD. The findings and results of this project were published by Kort and van Hoof [4].

The BEZO project was conducted from 2013 to 2015 at a nursing home in the Netherlands, which also has small scale living facilities for older people (6-10 residents per group), most of whom have dementia. The project was initiated on request of the board of directors, who aimed to transform their home into an enriched environment for the benefit of both residents and staff. The project focused on the environment in two identical common rooms in the home. The selection of the participants was based on informed consent and the willingness of the residents and/or their legal representatives who were also invited to join the project. Professionals working as caregivers in these common rooms also participated. The goal was to translate the vision of the board to enhance the indoor environmental quality of one common room for the benefit of residents and staff through design features and practical methods, while the other common room kept its status quo. No instructions were given to staff or residents after the indoor environmental quality interventions had been implemented and the one common room was modified. The results of the acoustic intervention and the participatory design approach were published by Huisman et al. in 2017 [5] and 2018 [6], respectively. 
Kort et al.: Research Methods for Involving People with Dementia

The MedGUIDE project started in 2017 and will end in 2019. Because the project is in progress, no findings and results have been published, but more information can be found on the project website [7]. Twenty-one percent of PwD are exposed to polypharmacy but their cognitive decline makes it challenging for them to self-manage their disease, including taking their medication. This project was initiated by a consortium which identified that medication adherence for PwD could be improved. This consortium consists of both businesses (in Cyprus, Norway, Switzerland and the Netherlands) and universities (in the Netherlands and Romania). End users, or primary users participating in the project, are people with early (selfreported) dementia or mild cognitive impairment who use 3 or more medicines and have a signed informed consent by them or a legal representative. Other users in the project are secondary users, being family caregivers and professional caregivers, and tertiary users, being pharmacists and medical doctors. The first phase was conducted over 9 months and included 7 persons with dementia and 10 next of kin, 8 secondary users and 5 tertiary users. PwD were interviewed at home or in a group session at the day care, while secondary and tertiary users were interviewed together on campus. The goal of the project is to develop a smart pill box platform that allows PwD to self-manage their medication intake while also providing information to secondary and tertiary users about their medication adherence.

The VETO project (Nursing Home of the Future) started in 2014 and ended in 2017 as part of a larger research program. The project focuses on the study and creation of a "sense of home" in the nursing home. The sense of home of nursing home residents is a multifactorial phenomenon important for the quality of living. This purpose of the study was to investigate the factors influencing the sense of home among older adults residing in the nursing home from the perspective of residents, their relatives and care professionals. 24 residents and 18 relatives participated in 4 nursing homes in the Netherlands in a photoproduction study with subsequent interviews [8]. The methodology had been tested before in a gerontopsychiatric nursing home population [9].

The SCHAT project (Smart Care Homes and Assistive Technologies) project started in 2015 and concluded in 2018. The project utilized a work package structure with one work package focused on older PwD and their informal caregivers [10]. The project concerns real-time location systems (RTLS) which can be implemented in aged care for monitoring persons with wandering behavior and asset management. RTLS can help retrieve personal items and assistive technologies that, when lost or misplaced, may have serious financial, economic and practical implications. Various ethical questions arose during the design and implementation phases of RTLS. The work package investigated the perspectives of various stakeholders on ethical questions regarding the use of RTLS for asset management in nursing homes. One focus group session was conducted concerning the needs and wishes of residents $(n=2)$ and their relatives $(n=4)$ [11].

In the aforementioned projects, several qualitative methods were used. An overview of the methods and instruments used is given in Table 1.

\section{Results}

Various methods could be combined in order to meet the goal of a project involving PwD and their carers. For the DAD project, PwD were observed during consultation sessions for their navigation skills and patterns using a personal computer. At the same session, PwD and their spouses were consulted about the features they liked and disliked about a selection of existing websites.

For the BEZO project, observations were made in order to score the residents' activities and their viewing direction from the perspective of the indoor light conditions in both a modified shared living room as in a nonmodified room. These methods encompass a passive involvement of PwD. At the start of the BEZO project, the more fluently speaking residents and their relatives, as well as staff and board members, contributed to a development session for interventions to the indoor environment and the design of the common living room.

During the MedGUIDE project, observations, storytelling and the think-aloud methods were used. First, storytelling sessions were held during which the PwD spoke about the structure and routines in their daily life. The goal was to adjust the system that was to be developed to these individual needs. Moreover, PwD gave feedback using "talking sheets" which contained examples of applications and/or systems which are already used for 
Table 1. Overview of research methods for the inclusion of PwD

\begin{tabular}{|c|c|c|c|c|c|}
\hline $\begin{array}{l}\text { Method used } \\
\text { for involvement }\end{array}$ & $\begin{array}{l}\text { PwD } \\
\text { target }\end{array}$ & $\begin{array}{l}\text { Grade of } \\
\text { activity }\end{array}$ & $\begin{array}{l}\text { Approach for/ } \\
\text { relevant outcomes }\end{array}$ & Instruments used & $\begin{array}{l}\text { Applied in } \\
\text { project }\end{array}$ \\
\hline \multirow[t]{3}{*}{ Observations } & \multirow[t]{3}{*}{ All } & \multirow[t]{3}{*}{+} & $\begin{array}{l}\text { Observations during the first } \\
\text { consultation round were an implicit part } \\
\text { of the DAD project; movements and } \\
\text { activity of the participants in the } \\
\text { consultation rounds were observed to } \\
\text { assess the capacity of PwD in using a PC } \\
\text { The PC was operated by the spouse } \\
\text { without dementia }\end{array}$ & $\begin{array}{l}\text { DAD scoring-list for } \\
\text { keyword search and } \\
\text { PC-operating activities [4] }\end{array}$ & \multirow[t]{3}{*}{$\begin{array}{l}\text { DAD, BEZO } \\
\text { MedGUIDE }\end{array}$} \\
\hline & & & $\begin{array}{l}\text { BEZO project: residents of the common } \\
\text { room with no intervention were also } \\
\text { present in the room in which the } \\
\text { intervention was executed; the speech } \\
\text { intelligibility }\left[{ }^{13}\right] \text { and light conditions } \\
\text { were improved in the intervention room } \\
{\left[{ }^{14}\right] \text {, and all PwD being residents of that }} \\
\text { room received a private space in the } \\
\text { room cabinet }\end{array}$ & $\begin{array}{l}\text { BEZO scoring for their } \\
\text { behavior/viewing } \\
\text { direction from a light } \\
\text { context based on van Hoof } \\
\text { et al. [12] (2012) }\end{array}$ & \\
\hline & & & $\begin{array}{l}\text { MedGUIDE project during the home } \\
\text { visits, the PwD and next of kin were } \\
\text { observed by the interviewer and } \\
\text { asked to show their daily routines in } \\
\text { medication storages and reminders } \\
\text { and routines of intake; pictures were } \\
\text { taken of these situations }\end{array}$ & $\begin{array}{l}\text { MedGUIDE observations } \\
\text { were done according to } \\
\text { the research protocol [7] } \\
\text { during the at-home visits } \\
\text { to get insight in PwD daily } \\
\text { routines }\end{array}$ & \\
\hline Consultations & $\begin{array}{l}\text { Early } \\
\text { dementia }\end{array}$ & ++ & $\begin{array}{l}\text { Three consultation rounds were held; } \\
\text { the first consultation round concerned } \\
\text { the determination of participants' view } \\
\text { on websites in general } \\
\text { The second consultation round } \\
\text { examined how participants search for } \\
\text { information about dementia-friendly } \\
\text { housing and which keywords they use } \\
\text { in this search } \\
\text { A third consultation round was } \\
\text { scheduled to gather feedback about the } \\
\text { developed demonstration version of the } \\
\text { website } \\
\text { Participants' expectation was that the } \\
\text { website to be designed should contain } \\
\text { relevant information about home } \\
\text { modifications } \\
\text { A relevant outcome is that the } \\
\text { website has to be designed accessibly } \\
\text { comparable to reading a book }\end{array}$ & $\begin{array}{l}\text { USE questionnaire [15] } \\
\text { Demonstration website } \\
\text { designed based on } \\
\text { consultation findings } \\
\text { Questions based on } \\
\text { Krout's seven as for } \\
\text { community support [16] } \\
\text { Google Analytics to } \\
\text { assess the use of the } \\
\text { demonstration website }\end{array}$ & DAD \\
\hline Storytelling & $\begin{array}{l}\text { Early } \\
\text { onset }\end{array}$ & +++ & $\begin{array}{l}\text { This approach was used to get a better } \\
\text { understanding about the daily life of } \\
\text { PwD; a relevant outcome is that PwD } \\
\text { have accommodated to a very structured } \\
\text { daily routine so they can receive } \\
\text { reminders for their medication intake }\end{array}$ & $\begin{array}{l}\text { Open structured } \\
\text { interviews }\end{array}$ & MedGUIDE \\
\hline $\begin{array}{l}\text { Focus group } \\
\text { sessions }\end{array}$ & $\begin{array}{l}\text { Moderate } \\
\text { dementia }\end{array}$ & $++/+++$ & $\begin{array}{l}\text { This approach was used to get a better } \\
\text { understanding of how older people } \\
\text { with dementia see the ethical aspects of } \\
\text { track and trace technologies for asset } \\
\text { management }\end{array}$ & $\begin{array}{l}\text { Semistructured approach } \\
\text { to questions }\end{array}$ & SCHAT \\
\hline
\end{tabular}


Dementia

Cognitive Disorders

\begin{tabular}{l|l}
\hline \multicolumn{2}{l}{ Dement Geriatr Cogn Disord 2019;47:149-156 } \\
\hline DOI: 10.1159/000497802 & $\begin{array}{l}\text { @ 2019 S. Karger AG, Basel } \\
\text { www.karger.com/dem }\end{array}$ \\
\hline
\end{tabular}

Kort et al.: Research Methods for Involving People with Dementia

Table 1 (continued)

\begin{tabular}{|c|c|c|c|c|c|}
\hline $\begin{array}{l}\text { Method used } \\
\text { for involvement }\end{array}$ & $\begin{array}{l}\text { PwD } \\
\text { target }\end{array}$ & $\begin{array}{l}\text { Grade of } \\
\text { activity }\end{array}$ & $\begin{array}{l}\text { Approach for/ } \\
\text { relevant outcomes }\end{array}$ & Instruments used & $\begin{array}{l}\text { Applied in } \\
\text { project }\end{array}$ \\
\hline $\begin{array}{l}\text { Thinking-aloud } \\
\text { sessions }\end{array}$ & $\begin{array}{l}\text { Early } \\
\text { onset }\end{array}$ & +++ & $\begin{array}{l}\text { This approach was used to receive } \\
\text { instant feedback from PwD for the } \\
\text { clickable design of the MedGUIDE } \\
\text { platform which was shown at their } \\
\text { home; the outcome is that they wished } \\
\text { the system to be personalized and the } \\
\text { ICT skills needed to use the tool should } \\
\text { be easily accessible taking into account } \\
\text { all the levels of health literacy; they } \\
\text { really liked the reliable information } \\
\text { about the diagnoses and prognosis of } \\
\text { dementia }\end{array}$ & $\begin{array}{l}\text { Clickable design of the } \\
\text { platform }\end{array}$ & MedGUIDE \\
\hline $\begin{array}{l}\text { Photo-production } \\
\text { and interviews }\end{array}$ & $\begin{array}{l}\text { Early } \\
\text { onset / } \\
\text { moderate } \\
\text { dementia }\end{array}$ & ++ & $\begin{array}{l}\text { A visual research method was chosen, in } \\
\text { which people are interviewed based on } \\
\text { photographs they have taken themselves } \\
\text { with cameras supplied to them by the } \\
\text { research team; photography allows } \\
\text { participants to create a record of an } \\
\text { event, capture a complex phenomenon } \\
\text { or to tell a story through images; as } \\
\text { taking photos does not rely on language } \\
\text { alone, it can be used with vulnerable or } \\
\text { frail populations who might not } \\
\text { normally be included in research; a } \\
\text { photo only serves as a conduit to } \\
\text { enhanced, thoughtful and deliberative } \\
\text { narrative, instead of as a replacement of } \\
\text { words; photography allows complex } \\
\text { environmental, health and social issues } \\
\text { to be captured and then shared with } \\
\text { other people; the photoproduction } \\
\text { method enables researchers to } \\
\text { experience a phenomenon from another } \\
\text { point of view }\end{array}$ & $\begin{array}{l}\text { Semistructured approach } \\
\text { to interview questions } \\
\text { supplemented by } \\
\text { photographs }\end{array}$ & VETO \\
\hline
\end{tabular}

+, passive (no conversation); ++, intermediate, i.e. saying some sentences/words; +++, active (complete conversations).

supporting the medication adherence. These sessions were conducted at the PwD's home to gain a better understanding of their daily routines in the search of finding reminders for medication adherence. Based on the findings of the storytelling phase, a clickable design of the MedGUIDE platform was designed, and researchers collected PwD feedback and suggestions for improvement in so-called mock-up sessions. When possible, respondents participated in both the requirements phase and the mock-up sessions.

For the VETO project, PwD, their family carers and professional carers were invited to take photographs in a study in which they had to capture the essence of their sense of home in terms of facilitators and hindrances. At the end, when the photographs were available, individual interviews about the contents of the photos were held with PwD, and focus group sessions were conducted with the carers. Finally, a comparison of findings was made.

In the SCHAT project, older PwD were involved in focus group sessions, but given the complexity and abstract levels of thinking that are required in thinking about new technol- 
ogies and ethical aspects, the input was rather basic. The actual participation in the project was deemed more important than the actual contribution.

In Table 1 an overview of methods used is given.

\section{Discussion/Conclusion}

Older people with early-stage dementia are very capable of contributing as participants in scientific studies. They are able to take an active role as co-creator of solutions to accommodate to their life when living with dementia. For those PwD whose speech is still fluent and not affected by the syndrome, active engagement in interviews and focus groups should always be considered. The methods used were supported with validated instruments in order to gather the instant opinion or feeling of PwD concerning the solution developed or topic studied. People with early-stage dementia are able to share and communicate their daily life routines in spoken words. Other methods based on visual and tactile capacities could also be considered in studies, as other sensory stimuli can come into action as a way of method triangulation. Such methodologies include the use of the visual-assessment (sensing) methods, which use photos and images taken by users to express what they feel about the item or image chosen or making mood boards with PwD in order to indicate what type of interior design PwD wish [17]. Another method which should be explored in relation to the involvement of PwD in research is the LEGO Serious Play method [18], in which people are stimulated to engage in storytelling activities based on a small-scale model made with LEGO bricks (or even LEGO DUPLO bricks). Such visually enhanced methods, including the aforementioned photoproduction methodology, can also be used when PwD are not fully able to engage in lengthy interview sessions, and when they require visual support to express themselves. The goal is to move user-centered design into actual participatory design, in which the active inclusion of PwD may be seen as an emancipatory step in dealing with dementia in society. Participatory design breaks away from the traditional designer-user relationship, and the designer or design-researcher acknowledges the empirical expertise of the user on the given subject. The user is therefore participating in the process as an active co-creator, rather than as a subject of research. Apart from product design, or the design of environments, similar approaches could also be used for service design, including the creation of new health care services for older PwD that are tailored towards the actual needs.

In future studies PwD and their relatives should have a more prominent role as co-creators or co-producers of technological solutions. Researchers should be challenged to offer the most appropriate methods for this goal. Therefore, a more systematic study about the pros and cons about the various methods for co-creation sessions with PwD should be executed.

\section{Acknowledgement}

The authors wish to express their gratitude to the older people living with dementia, their partners and family carers who participated in the projects.

\section{Statement of Ethics}

The authors have no ethical conflicts to disclose. The BEZO project was approved by the client board of the studied location of the participating nursing home organization. For the MedGUIDE project, the need for ethical approval was waived (report 17-321/C). In the DAD, VETO and SCHAT projects, informed consent was obtained from the participants in line with the recommendations for ethics in research. 
Kort et al.: Research Methods for Involving People with Dementia

\section{Disclosure Statement}

The authors have no conflicts of interest to declare.

\section{Funding Sources}

The projects were funded as followed: the DAD project was part of the Future Care (Zorg(en) voor Morgen) project from the Taskforce Innovation Region Utrecht, Pieken in de Delta Grant No. PID 082028. The BEZO project, VETO project and SCHAT project were co-funded by the Regional Attention and Action for Knowledge Circulation (RAAK) scheme, which is managed by the Foundation Innovation Alliance (SIA, Stichting Innovatie Alliantie) with funding from the Dutch Ministry of Education, Culture and Science (OCW) (SIA project No. 2012-14-38P, 2014-01-05P and 2015-02-24M). The MedGUIDE project is co-funded under the AAL funding scheme under the European Union (ZonMw 70-73500-92-031), executed in the Netherlands by the national body ZonMw.

\section{Author Contributions}

Helianthe Kort contributed to the design and writing of the text related to the BEZO, DAD and MedGUIDE projects. Bas Steunenberg contributed to the text for the MedGUIDE-project. Joost van Hoof contributed to the design and writing of the text related to the VETO, SCHAT and DAD projects.

\section{References}

1 Patterson C. World Alzheimer report 2018. The state of the art of Dementia research: New Frontiers. Alzheimer's Disease International (ADI), London. Available from: https://www.alz.co.uk/research/ WorldAlzheimerReport2018.pdf

2 Toot S, Swinson T, Devine M, Challis D, Orrell M. Causes of nursing home placement for older people with dementia: a systematic review and meta-analysis. Int Psychogeriatr. 2017;29(2):195-208. D0I: 10.1017/ S1041610216001654.

3 Verbrugge LM, Jette AM. The disablement process. Soc Sci Med. 1994;38(1):1-14. DOI: 10.1016/02779536(94)90294-1.

4 Kort HSM, van Hoof J. Design of a website for home modifications for older persons with dementia. Technol Disabil. 2014;26(1):1-10. DOI: 10.3233/TAD-140399.

5 Huisman ERCM, van Hout NHAM, Reinten J, Kort HSM. Steps towards an acoustical intervention in a nursing home for the benefit of residents and staff: a case study. Gerontechnology (Valkenswaard). 2017;16(4):24956. DOI: $10.4017 /$ gt.2017.16.4.007.00.

6 Huisman ERCM, Appel-Meulenbroek HA, Kort HSM. A structural approach for the redesign of a small-scale care facility as a guideline for decision-makers. Intelligent Buildings International; 2018. DOI: $10.1080 / 17508975.2018 .1493569$.

7 http://medguide-aal.eu/

8 van Hoof J, Verbeek H, Janssen BM, Eijkelenboom A, Molony SL, Felix E, et al. A three perspective study of the sense of home of nursing home residents: the views of residents, care professionals and relatives. BMC Geriatr. 2016;16(1):169. DOI: 10.1186/s12877-016-0344-9.

9 van Hoof J, Verhagen MM, Wouters EJM, Marston HR, Rijnaard MD, Janssen BM. Picture your nursing home. Exploring the sense of home of older residents through photography. J Aging Res. 2015;2015:312931. DOI: $10.1155 / 2015 / 312931$.

10 van Hoof J, Douven B, Janssen BM, Bosems WP, Oude Weernink CE, Vossen MB. Losing items in the psychogeriatric nursing home: the perspective of residents and their informal caregivers. Gerontol Geriatr Med. 2016; 2:1-9. DOI: $10.1177 / 2333721416669895$.

11 van Hoof J, Verboor J, Oude Weernink CE, Sponselee AAG, Sturm JA, Kazak JK, et al. Real-time location systems for asset management in nursing homes: an explorative study of ethical aspects. Information. 2018;9(4):80. DOI: $10.3390 /$ info9040080.

12 van Hoof J, Westerlaken AC, Aarts MPJ, Wouters EJM, Schoutens AMC, Sinoo MM, et al. Light therapy: methodological issues from an engineering perspective. Technol Health Care. 2012;20(1):11-23. DOI: 10.3233/ THC-2011-0650. 
13 Reinten J, van Hout NHAM, Hak CCJM, Kort HSM. Measurements of speech intelligibility in common rooms for older adults as a first step towards acoustical guidelines. In: C. Sik-Lanyi, E-J. Hoogerwerf, K. Miessenberger and P. Cudd, editors. Assistive technology: building bridges. Studies in health technology and informatics. Amsterdam: IOS Press; 2015. p. 415-22. DOI: 10.3233/978-1-61499-566-1-415.

14 Huisman ERCM, Kort HSM. 2015. Creating healthy nursing home environment via lighting interventions: a theoretical approach. In: C. Sik-Lanyi, E-J. Hoogerwerf, K. Miessenberger and P. Cudd, editors. Assistive technology: building bridges. Studies in health technology and informatics. Amsterdam: IOS Press; 2015. Vol. 217, p. 411-414. DOI: 10.3233/978-1-61499-566-1-411.

15 Lund AM. Measuring usability with the USE Questionnaire12. Usability Interface. 2001;8(2):3-6.

16 Krout J. An overview of older rural populations and community based services. In: Krout J, editor. Providing community-based services to the rural elderly. Thousand Oaks (CA): SAGE Publications, Inc.; 1994. pp. 3-19., http://bit.ly/2kS0xWX

17 van Hoof J, Sprong M, Janssen B. Wanneer voel je je thuis? Op zoek naar het thuisgevoel van mensen met dementie. Denkbeeld. 2015;27(5):22-4. DOI: 10.1007/s12428-015-0102-3.

18 Wouters EJM, van Hoof J. Professionals' views of the sense of home in nursing homes: findings from LEGO SERIOUS PLAY workshops. Gerontechnology (Valkenswaard). 2017;16(4):211-6. DOI: 10.4017/ gt.2017.16.4.002.00. 